\section{Detection by Radar of a New Meteor Shower}

British Astronomical Association Circular No. 282 gives a short note from Dr. A. C. B. Lovell, director of radar research on meteors at the University of Manchester, who has announced the discovery of a new shower during daylight. For some time radio reflexion has been used to study the ionization caused by meteors in the upper atmosphere (see Nature, July 19 , pp. 74 and 76). Certain radiants have been selected and studied carefully by means of a beam of radiation about $\pm 6^{\circ}$ wide which can be directed to any point in the heavens, and Mr. J. A. Clegg has devised a method by which it is possible to determine very accurately the radiant of a stream. No details about this method have been published up to the present, but it may be assumed that it is capable of providing more accurate results than those obtained from visual observations. It is interesting to know that the investigation of the radiants of the well-known showers during the autumn and winter shows, apart from minor variations, that the radiants determined by Mr. J. P. M. Prentice, director of the Meteor Section, British Astronomical Association, and his colleagues, agree closely with those found by Mr. Clegg's method.

The investigation of the $\eta$ Aquarid stream was commenced on May 1, and it was obvious that this well-known stream was merely the beginning of a very active belt stretching towards the sun, the main radiant point of this stream lying in the constellation of Pisces. As this latter radiant crossed the meridian at about 10h.-1lh., depending on the period of observation in May, no knowledge of this shower was possible from visual observation. The Aquarius end of this belt disappeared in mid-May; but the Piscid radiant continued with great intensity, and on June 22 the shower, which had continued for 35 days, was still active, the radiant being now in Taurus, and showed no signs of ending. While fluctuations in intensity have occurred, the hourly rate at transit has often exceeded 80 and has never fallen below 20 . Preliminary analysis has given the following approximate positions of the new radiant:

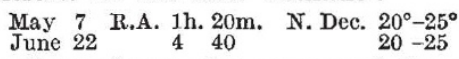

Minor radiants have also appeared for a few days about $15^{\circ} \mathrm{W}$. and $10^{\circ} \mathrm{E}$. of the main knot, but at the same declination, and on some occasions the whole area between these extremes has been active.

\section{Institutum Divi Thomæ: Extension of Facilities}

THE Donner Foundation, Inc., the head of which is William H. Donner, of Philadelphia, has given a 64-room building in Palm Beach, Fla., to the Institutum Divi Thomæ, of Cincinnati, Ohio, for scientific research. The building, to be known as Donner Hall, was formerly a part of the estate of the late Colonel E. R. Bradley, and is adjacent to Bradley Hall, now occupied by the marine biological laboratories of the Institutum Divi Thomæ. Dr. George S. Sperti, director of the Institutum, states that Donner Hall will provide quarters for what is planned eventually to be the largest marine biophysics laboratory in the world; the Institutum already maintains a floating laboratory, the Aquina, which will become part of this programme. Secondly, since cancer in its simplest terms is a problem in cell division, and since lower forms of sea life offer convenient material for studying cell reproduction, Donner Hall will provide for intensive fundamental research in cancer. Finally, it will pro. vide quarters for visiting scientific workers from various parts of the world, who will be invited to participate in a series of symposia devoted to different fields of research. The Institutum Divi Thomæ, founded in 1935 by the Most Rev. John T. MeNicholas, Archbishop of Cincinnati, as a graduate research school, open to all scientific workers regardless of race, colour or creed, now has fourteen affiliated units throughout the United States; it has already been responsible for important work in various fields, notably biochemistry and biophysics. William $\mathrm{H}$. Donner, whose generosity has opened the way to the establishment of the new cancer research centre, has previously given large sums for the study of cancer. $\mathrm{He}$ was born in Columbus, Ind., in 1864, and is a Presbyterian. Beginning as treasurer of the National Tin Plate Company at Anderson, Ind., Mr. Donner built its plate works near Pittsburgh and founded Monessen, Pa., before the company was absorbed by the American Tin Plate Company. He then built up another steel corporation in the same way until it became part of the Union Steel Company, which in turn was purchased by the United States Steel Corporation.

\section{Television in the United States}

The Radio Corporation of America has played a prominent pioneer part in the practical development of television in the United States, more particularly since 1923, when Dr. V. K. Zworykin applied for a patent on the now world-famous iconoscope. Much of this pioneer work has been inspired by Brigadier General Sarnoff, president of the Radio Corporation of America, and it is the purpose of an illustrated booklet recently issued by the Information Department of the Corporation (New York, 20) to present excerpts from General Sarnoff's statements on the subject at various public meetings and demonstrations during the past twenty-four years. Much of the results of the work conducted in the research laboratories of the R.C.A. is described in scientific and technical papers published in various journals, including the R.C.A. Review, to which reference was made in Nature of September 14, 1946 (p. 373). The publishers of this Review have now issued a biblio. graphy of technical papers on television by R.C.A. authors. This includes some 275 technical papers on television and closely related subjects published during the period 1929-46, and arranged generally in chronological order. This "Television Bibliography" is in the same handy size (about 9 in. $\times 6$ in.) as the R.C.A. Review, and should prove useful and convenient to all those concerned with the study, development and application of television. It is to be regretted that while the references give the year and month of publication, they do not give the volume and page number of the journal in question.

\section{Mesozoic Faunas of Peru}

Is 1941, Dr. William F. Jenks sent rich collections of fossils, made in the course of his field work in the Cerro de Pasco region of central Peru, to Dr. Otto Haas, of the American Museum of Natural History, New York, for identification. Ever since, a steadily increasing amount of Peruvian fossil invertebrates has been accumulating at the Museum. Collections made during 1943-46 by Dr. Norman D. Newell in central, eastern and southern Peru, by Mr. Bernhard Kummel in northern, central and eastern Peru, and by Dr. Jenks in southern Peru have since been added 